\title{
A ESTRUTURA DA MORAL KANTIANA
}

\author{
Francisco Eliandro Souza do Nascimento ${ }^{1}$ \\ Universidade Federal do Ceará (UFC) \\ https://orcid.org/0000-0003-1617-6134 \\ Francisco Rogelio dos Santos ${ }^{2}$ \\ Universidade Federal do Ceará (UFC)
}

\section{RESUMO:}

Neste artigo, faremos uma exposição da estrutura da moral kantiana partindo da análise dos seus principais pressupostos. Iniciaremos com a análise do conceito de homem em Kant, abordando as suas duas dimensões, racional e sensível, buscando uma compreensão da dualidade que se estabelece no nível da razão prática, entre o caráter empírico do sujeito prático e o caráter inteligível, e qual dessas duas dimensões se sobressaem no campo da ética. Em seguida trataremos da liberdade como princípio fundante da moral perguntando pela possibilidade de sua pressuposição, partiremos dos princípios fundamentais da moral kantiana, a saber, o conceito de liberdade, no sentido prático, a boa vontade como a porta de entrada para que a moralidade chegue ao seu acabamento, que é o cumprimento do dever, e o princípio de universalização da lei moral desenvolvido por Kant como o critério último de validação das normas.

PALAVRAS-CHAVE: Liberdade; Boa vontade; Dever; Moral.

\section{THE STRUCTURE OF KANTIAN MORAL}

\begin{abstract}
:
In this article, we will make an exposition of the structure of kantian moral starting from the analysis of its main assumptions. We will start from the concept of man in Kant, approaching his two dimensions, rational and sensible, seeking an understanding of the duality that is established at the level of practical reason, between the empirical character of the practical subject and the intelligible character, and which of these two dimensions stand out in the field of ethics. Then we will deal with freedom as the founding principle of morality, asking for the possibility of its presupposition, we will depart from the fundamental principles of Kantian morality, namely, the concept of freedom, in the practical sense, goodwill as the gateway for morality comes to its completion, which is the fulfillment of duty, and the principle of universalization of moral law developed by Kant as the ultimate criterion of validation of norms.
\end{abstract}

KEYWORDS: Freedom; Goodwill; Duty; Morals.

${ }^{1}$ Doutorando em Filosofia pela Universidade Federal do Ceará (UFC), Ceará - Brasil. Membro do Grupo de Pesquisa Direito, Moral e Política (GPOLIS) da Universidade Estadual Vale do Acaraú (UVA), Ceará - Brasil. E-mail: francisco_eliandro@hotmail.com

2 Mestre em Filosofia pela Universidade Estadual do Ceará ( UECE), Ceará - Brasil. E-mail: rogellyo@hotmail.com

NASCIMENTO, Francisco Eliandro Souza do; SANTOS, Francisco Rogelio dos. A estrutura da moral kantiana. Griot : Revista de Filosofia, Amargosa/Bahia, v.17, n.1, p.61-84, junho/2018. 
Immanuel Kant ${ }^{3}(1724$ - 1804) formulou uma concepção de filosofia prática de grande importância para o desenvolvimento posterior da filosofia. Ele é profundamente influenciado pela tradição filosófica racionalista de sua época e, posteriormente, pelo empirismo dos filósofos ingleses (Hume, Schaftesbury, Hutcheson e Locke). Os pensadores que mais o influenciaram foram, na filosofia teórica, David Hume, do qual afirmará mais tarde que "ele primeiro me despertou do sono dogmático e deu um outro rumo a minhas investigações no campo da filosofia especulativa." (Höffe apud KANT, 2005, p. 17). Na filosofia prática o filósofo alemão é influenciado por Jean Jacques Rousseau. Rousseau forneceu a Kant os:

\begin{abstract}
Elementos do conteúdo apriorístico da ética kantiana, concluindo uma prospectiva de independentização da ética anunciada em Montaigne, que se completa, em primeiro lugar, através do conceito de autonomia, compreendendo os conceitos de vontade e lei, com que Kant pretende vencer o problema da antinomia entre lei e liberdade, liberdade e bem, sollen e wollen. (SALGADO, 1995, p. 229).
\end{abstract}

Kant, no desenvolvimento crítico de sua filosofia, se ocupa dos problemas clássicos da metafísica, tais como os fundamentos da moral e as provas da existência de Deus. Segundo o filósofo, os problemas inevitáveis da razão pura são; Deus, a liberdade e a imortalidade, e "a ciência que, com todos os seus requisitos, tem por verdadeira finalidade a resolução destes problemas chama-se metafísica" (KANT, 2012, B 7). Para Kant, uma filosofia séria deve dedicar-se a questões fundamentais do homem, na medida em que se manifesta nele um interesse da razão, deste modo, os problemas inevitáveis em que a razão sempre despertou um interesse, Deus, liberdade e imortalidade, confluem nas quatro grandes perguntas: 1. Que posso saber? 2. Que devo fazer? 3. Que me é permitido esperar? 4. O que é o homem?

De acordo com Kant, nestas quatro perguntas estão os problemas mais importantes que sempre inquietaram, não apenas todos os filósofos, como também a própria humanidade. Estas são questões que a filosofia, enquanto metafísica, sempre se ocupou e que irão definir todo o projeto filosófico de Kant. Para cada uma destas perguntas, ele escreveu uma obra como resposta argumentada a estas questões. Em resposta à primeira pergunta, o filósofo escreveu sua obra mais célebre, Crítica da Razão Pura ${ }^{4}$, onde ele trata do problema da metafísica como ciência examinando as condições de possibilidade do conhecimento humano. Respondendo à segunda pergunta, Kant publica a Crítica da razão prática, em que formula as bases de sua ética fortemente racionalista. A terceira pergunta ele responde por meio da sua obra Crítica da faculdade de julgar, onde é considerada a "especificidade do juízo estético, embora essa obra não se limite à discussão sobre a estética, visando, em última análise, superar a dicotomia razão pura teórica (conhecimento) e razão prática moral." (MARCONDES, 2007, p. 110). Por fim, a quarta pergunta foi desenvolvida no livro Antropologia a partir de um ponto de vista pragmático, obra em que Kant trata

\footnotetext{
3 Historicamente, Kant pertence à época do Iluminismo europeu. A orientação geral desta época acreditava na ideia de que o homem pode dominar todas as coisas, no progresso constante da humanidade e, em geral, na confiança otimista na razão.

${ }_{4}^{4}$ A partir de agora será utilizado a sigla CRP para referenciar a obra Crítica da Razão Pura.
}

NASCIMENTO, Francisco Eliandro Souza do; SANTOS, Francisco Rogelio dos. A estrutura da moral kantiana. Griot : Revista 
da antropologia como uma ciência cuja "finalidade é preparar o homem para o conhecimento do 'mundo' (isto é, do mundo humano). Aqui, pois, o conhecimento do homem se funda no senso comum e tem em vista as relações que se estabelecem entre os homens." (VAZ, 1998, p. 97).

O filósofo alemão considera, porém, que as três primeiras questões se podem reduzir à quarta questão fundamental, dado que em filosofia é do homem que única e exclusivamente se trata. A primeira questão é de caráter especulativo em que a metafísica responde; a segunda de caráter prático cuja resposta vem da moral; a terceira é, simultaneamente, prática e teórica, sua resposta deriva da religião; e a quarta questão engloba as anteriores, pois, as três primeiras interrogações levam à última, em que a antropologia responde. Tavares, acerca da resposta kantiana às quatro perguntas, afirma que:

\begin{abstract}
A resposta à primeira pergunta pode sintetizar-se no seguinte: podemos conhecer a ordem dos fenômenos, no espaço e no tempo, sem ultrapassar os limites da experiência; podemos conhecer os princípios e os limites a partir dos quais e dentro dos quais é possível um conhecimento científico da natureza.

A resposta à segunda questão é: devemos cumprir o nosso dever e fazer o que nos torna dignos da felicidade; devemos estabelecer os princípios da acção e as condições da liberdade.

A resposta à terceira pergunta, que aliás se liga à segunda, é: podemos esperar o Soberano Bem, síntese da virtude e da felicidade; é lícito esperar a felicidade na medida em que cada um de nós, pela sua conduta, pelo cumprimento da lei moral, se pode tornar digno dela, trata-se de delinear, projectivamente, o destino último do homem e as condições da sua realização.

Respondendo à quarta questão, o homem é um ser racional finito, sensível e moral. Como ser sensível ou fenoménico, pertence a uma espécie animal e a uma ordem natural, mas é também um ser racional que se rege, na sua conduta, por princípios morais. Neste sentido, o homem é natureza e liberdade, ser fenoménico e numénico, sujeito às leis da natureza, mas não totalmente determinado por elas. Só como ser numénico merece a designação de racional. A racionalidade é uma conquista, resulta de um esforço de auto-aperfeiçoamento. Pessoa e animal, razão e natureza, liberdade e necessidade, lei moral e lei natural, são os elementos que constituem a natureza humana. (TAVARES, 1995, p. 80).
\end{abstract}

Kant elabora uma concepção de homem, "onde a tradição racionalista e 'ilustrada' deve compor-se com a herança pietista ${ }^{5}$ e com a poderosa atração do pensamento de J.-J. Rousseau," (VAZ , 1998, p. 95), para formular a ideia de

\footnotetext{
5 A herança pietista de Kant refere-se ao movimento religioso, denominado Pietismo, de "reação contra a ortodoxia protestante que ocorreu no norte da Europa, especialmente na Alemanha, na segunda metade do século XVII. Foi comandado por Phillipp Spener (1635-1705), e um de seus expoentes foi o pedagogo August Franke (1663-1727). O Pietismo pretendia voltar às teses originais da Reforma protestante: livre interpretação da Bíblia e negação da teologia; culto interior ou moral de Deus e negação do culto externo, dos ritos e de qualquer organização eclesiástica; compromisso com a vida civil e negação do valor das denominadas "obras" de natureza religiosa. Deste último aspecto deriva a aceitação de muitos ensinamentos de caráter prático e utilitário nas instituições educacionais pietistas". (ABBAGNANO, 2007, p.795).
}

NASCIMENTO, Francisco Eliandro Souza do; SANTOS, Francisco Rogelio dos. A estrutura da moral kantiana. Griot : Revista 
homem. Levando-se em conta essas duas influências, são traçadas duas linhas de desenvolvimento da concepção do homem em Kant. Vejamos:

1) "Uma linha propriamente antropológica, cuja origem deve ser buscada no curso de Metafísica professado por Kant e para o qual utiliza o compêndio de Baumgartner. Aqui Kant introduz a partir de 1762 uma alteração decisiva no melhor estilo da Ilustração, colocando no início o estudo empírico do homem ao qual dá o título de antropologia;" (VAZ , 1998, p. $96)^{6}$

2) “Uma linha crítica que segue o desenvolvimento da reflexão crítica a partir da dissertação de 1770; na verdade, essa tarefa crítica que abrange as três atividades superiores do homem, a razão teórica, a razão prática e a faculdade de julgar, traz consigo uma profunda remodelação da imagem do homem transmitida pelo racionalismo clássico." (VAZ , 1998, p. 96).

No conceito de homem em Kant, tomando como referência essas duas linhas, é observável a subordinação da antropologia, cuja base é empírica, à metafísica dos costumes, que procede a priori. A concepção kantiana de homem estrutura-se sobre dois planos epistemológicos, "o plano de uma ciência de observação que utiliza o procedimento analítico para unificar os dados da observação por meio de uma teoria das faculdades", razão teórica, e o "plano de uma ciência a priori que situa no campo da ética ou da metafísica dos costumes a possibilidade de determinação da essência do homem," (VAZ, 1998, p. 96), razão prática.

No que concerne à ideia de homem em Kant, o pensamento crítico do filósofo não se distancia da linha da tradição dualista própria da antropologia racionalista. Vaz, acerca do conceito kantiano do homem, cita que:

Esse dualismo constitui mesmo uma estrutura conceptual fundamental do edifício crítico, seja no nível da Razão pura, seja no nível da Razão prática. Com efeito, no nível da Razão pura, encontramos uma dualidade estrutural entre a sensibilidade receptiva e a espontaneidade do entendimento, e entre este como domínio do condicionado e a Razão (Vernunft) como domínio do incondicionado. No nível da Razão prática, a dualidade se estabelece entre o "caráter empírico" do sujeito prático (domínio da necessidade externa e das paixões) e o seu "caráter inteligível" (domínio da liberdade). (VAZ, 1998, p. 98).

Kant, em relação à razão prática, afirma que o homem, ao contrário das coisas que atuam mecanicamente, possui a capacidade de agir segundo normas, pois somente ele possui uma razão. A grandeza do homem, segundo o filósofo alemão,

\footnotetext{
${ }^{6}$ Kant aborda em especial o tema da antropologia em sua obra "A Antropologia desde o ponto de vista pragmático" (1798). Nesta obra o filósofo trata do conceito de Antropologia ao contrário da antropologia moral. A Antropologia de um ponto de vista pragmático, "revela-se independente do programa da filosofia crítica, visto que na referência direta ao real para mediar o conhecimento, Kant a apresentou como uma antropologia para práxis da vida e para a "experiência comum", e por isso, ela pode ser entendida como uma teoria da práxis da vida. Esta linha de pensamento diferencia-se fundamentalmente da filosofia crítica e da matemática. Enquanto na filosofia pura devem suceder princípios a priori de definição clara e segura de uma fundamentação última e suficiente, para a Antropologia é precedente não a fundamentação última, mas a utilização do conhecimento do homem sobre a práxis da vida. (MARTINS, Introdução da obra "A Antropologia desde o ponto de vista pragmático", 2006, p. 12)
}

NASCIMENTO, Francisco Eliandro Souza do; SANTOS, Francisco Rogelio dos. A estrutura da moral kantiana. Griot : Revista 
consiste em sua capacidade de autodeterminar-se a partir da razão prática. A questão em Kant, relacionada à filosofia prática, consiste em saber como justificar e determinar a validade das normas de ação, pois, o filósofo tem como objetivo tematizar o princípio de fundamentação das normas e estabelecer uma medida suprema, a partir da qual se possa decidir a moralidade das normas de ação. $O$ pensamento de Kant no nível da ética constitui uma revolução na filosofia moral, pois, o filósofo introduz, na filosofia prática, "um novo conceito de ética e de sua tarefa fundamental. De agora em diante, não é tarefa da ética o estabelecimento de normas para a ação humana, sua função vai "consistir no estabelecimento do princípio de validade das normas de ação." (OLIVEIRA, 1993, p.141). Vejamos no tópico a seguir a revolução filosófica de Kant na filosofia teórica e prática.

\title{
A revolução kantiana na filosofia prática
}

A filosofia kantiana, seja no campo teórico ou prático, constitui uma verdadeira revolução no pensamento filosófico ocidental. ${ }^{7}$ Kant realizou na história da filosofia uma mudança semelhante à que Nicolau Copérnico desenvolveu na ciência de seu tempo. Assim como Copérnico inverteu a ordem das coisas com sua teoria do Heliocentrismo ${ }^{8}$, Kant realiza semelhante movimento em sua filosofia transcendental, ao deslocar a direção do pensar filosófico do objeto para o sujeito. Vejamos uma passagem da Crítica da Razão Pura em que Kant assemelha sua filosofia com a primeira ideia de Copérnico, fazendo menção à nova maneira de pensar a tarefa da filosofia. Cita o filósofo:

\begin{abstract}
Até hoje admitia-se que nosso conhecimento se devia regular pelos objetos; porém, todas as tentativas para descobrir a priori, mediante conceitos, algo que ampliasse o nosso conhecimento, malogravam-se com este pressuposto. Tentemos, pois, uma vez, experimentar se não se resolverão melhor as tarefas da metafísica, admitindo que os objetos se deveriam regular pelo nosso conhecimento, o que assim já concorda melhor com o que desejamos, a saber, a possibilidade de um conhecimento a priori desses objetos, que estabeleça algo sobre eles antes de nos serem dados. Trata-se aqui de uma semelhança com a primeira idéia de Copérnico; não podendo prosseguir na explicação dos movimentos celestes enquanto admitia que toda a multidão de estrelas se movia em torno do expectador, tentou se não daria melhor resultado fazer antes girar o expectador e deixar os astros imóveis (KANT, 2012, B XVI).
\end{abstract}

\footnotetext{
7 Segundo Vázquez, "Foi Hegel o primeiro a enxergar na filosofia kantiana uma revolução ou, mais exatamente, o ponto de partida de uma revolução que acha em seu próprio sistema seu ponto culminante. Seu objeto não é o mundo, o ser em si da metafísica tradicional, mas o conhecimento (ou pretensões de conhecimento) do mundo ou do ser" (VÁZQUEZ, 2002. p. 194).

${ }^{8}$ Heliocentrismo é a teoria a respeito do sistema cosmológico, segundo a qual a Terra e os demais planetas giram em torno do Sol, esta teoria era oposta ao geocentrismo, que colocava a Terra no centro do universo. Nicolau Copérnico, um polonês que viveu entre 1453 - 1543, é considerado o fundador da astronomia moderna e pai do heliocentrismo. Em 1514, Copérnico divulgou um modelo matemático no qual a Terra e os demais corpos celestes giravam em torno do Sol, contrário ao modelo geocêntrico aceito pela maioria, e defendido pela Igreja por aproximadamente 1400 anos. $O$ sistema geocêntrico ou ptolomaico descrevia um modelo no qual a Terra seria o centro do Universo, que aliás, seria finito.
}

NASCIMENTO, Francisco Eliandro Souza do; SANTOS, Francisco Rogelio dos. A estrutura da moral kantiana. Griot : Revista de Filosofia, Amargosa/Bahia, v.17, n.1, p.61-84, junho/2018. 
Esta revolução que Kant realizou na estrutura da filosofia é denominada por muitos de revolução copernicana ${ }^{9}$, por ter invertido a ordem das coisas no plano teórico e prático. Segundo Kant, nosso conhecimento não deveria regular-se pelos objetos, como era compreendido na metafísica tradicional, e sim os objetos que devem regular-se sobre nosso conhecimento. Perante tal mudança, Kant inaugura um novo paradigma no plano do conhecimento teórico que marcará a sua filosofia como revolução crítica ${ }^{10}$ ou criticismo ${ }^{11}$ kantiano.

De acordo com Vázquez, acerca do caráter revolucionário da filosofia de Kant:

O caráter revolucionário da filosofia kantiana mostra-se portanto em sua relação com o passado, assim como em sua relação com o futuro, pelo caminho novo que abre ao pensamento filosófico com seu idealismo transcendental (juntamente por haver desenvolvido o lado ativo, embora de um modo abstrato - primeira tese sobre Feuerbach -, na relação sujeito - objeto) $)^{12}$ (VÁZQUEZ, apud Karl Marx, 2002, p. 194).

A virada revolucionária kantiana não se limita ao campo teórico, estende-se de forma impactante ao campo da filosofia prática. Kant ao elevar o homem como ser propriamente humano, tendo em vista como sujeito, autodeterminante e fim em si, embora o apresente em forma incompatível com a realidade natural, realiza também na esfera da filosofia prática uma verdadeira revolução. O filósofo de Köningsberg rompe radicalmente com a concepção tradicional do homem, determinado desde fora, seja em sentido naturalista, seja em sentido cristão, ele desenvolve sua filosofia prática opondo-se sistematicamente a qualquer forma de heteronomia ${ }^{13}$, seja ela derivada de uma "natureza", de uma lei divina, da tradição, dos costumes ou da autoridade. Na concepção kantiana, o homem ${ }^{14}$ é compreendido

\footnotetext{
9 Esta revolução desenvolvida por Kant, que foi denominada de "revolução copernicana", "revela os limites da razão teórica e a impossibilidade, dada sua constituição, de ultrapassar o campo da experiência possível, o campo dos fenômenos, para atingir o conhecimento da realidade em si" (FARIA, 2007. p. 122).

10 O termo crítica (Kritik) é compreendido na filosofia kantiana como investigação filosófica ou filosofia enquanto investigação que obedece ao seguinte roteiro sistemático: 1. valoração do objeto de estudo; 2. estabelecimento de informações acerca do objeto estudado e, ademais, apresentando como exigência metodológica primeiro expor e esclarecer as condições do conhecimento, para só então pretender-se produzir conhecimento.

${ }^{11}$ Por criticismo entendemos, "Método de investigação que consiste na instituição de um tribunal da razão (a razão julga-se a si própria), no sentido de estabelecer os limites da razão no domínio gnosiológico e, simultaneamente, investigar, nesse mesmo domínio, as suas possibilidades. Constitui um método de reabilitação da razão face ao cepticismo e, simultaneamente, uma crítica ao dogmatismo. O criticismo é já uma propedêutica à instituição da metafísica no domínio moral" (TAVARES, 1995, p. 80).

12 Karl Marx, "Tesis sobre Feuerbach", em Karl Marx e Friedrich Engels, La ideologia alemana, trad. De W. Roces, Ed. Pueblos Unidos, Montevidéu, 1969, p. 633.

13 Segundo Tavares e Ferro, o conceito de heteronomia opõe-se ao de autonomia, "na medida em que significa condicionamento, determinismo. O sujeito recebe do exterior a lei a que se submete. Kant identifica heteronomia com <<liberdade em sentido negativo $>>$, considerando que autonomia é $<<$ liberdade em sentido positivo $>>$ " (TAVARES, 1995, p. 147).

14 Faria ressalta que o homem kantiano "obedece apenas a si mesmo; é conduzido apenas por sua própria razão e pela consciência do dever, apesar do desejo que ameaça subordiná-lo indignamente à
} 
como fim em si que atua livremente e se determina a si mesmo e escapa às determinações do natural.

Outro ponto fundamental na filosofia prática kantiana, é que ela se opõe aos modelos tradicionais da ética ${ }^{15}$, pois, de acordo com Kant, os fundamentos apresentados pelos diversos filósofos, que serviam como base para suas formulações éticas, impediam que os mesmos chegassem a um acordo no campo da filosofia moral. A nova proposta moral de Kant se configura na absoluta autonomia da razão e se confirma por ser ela em si mesma legisladora. Para nosso filósofo, a fonte da moral não deve ser algo exterior ao próprio homem, como era proposto nos modelos éticos tradicionais, e sim algo interior ao próprio homem. A razão se configura na nova proposta de Kant como a responsável por legislar as normas morais que deverão conduzir e orientar as ações humanas. Na visão de Kant, a razão exerce a função prática de determinar a ação.

Faria, acerca da filosofia kantiana e os modelos tradicionais da ética, afirma que:

Ao invalidar a metafísica como ciência, Kant derruba o fundamento tradicional da ética. A queda da metafísica ameaçava arrastar consigo a ética, anulando os fundamentos e critérios invocados por ela até então. A ética tradicional, desde Aristóteles, se estrutura em torno da ideia de um bem que se apresenta como um fim visado em todos os atos humanos. Ora, a divergência quanto aos fins efetivamente visados pelo homem em todos os seus atos (felicidade, prazer, salvação da alma, auto-preservação) impediu que os diversos filósofos chegassem a um acordo no campo da ética. Acabam por enredar-se em dificuldades insuperáveis e são incapazes de responder à questão "o que devo fazer?", de forma universal e necessária. Kant tem uma concepção subjetivista de felicidade, diferente da visão aristotélica. $O$ que rejeita como possível fundamento da moral não é o conceito clássico de eudaimonia, que coincide com a autorrealização e a autossuficiência, mas o sentimento de "bem-estar" ou "satisfação". Kant quer "evitar as leis morais indulgentes que fazem concessões às fraquezas humanas". 16 Por estar marcado pela subjetividade, o conceito de felicidade é incompatível com uma ética que se pretende objetiva e universal. Sua ética dirige-se a seres racionais enquanto tais e deve manter-se alheia a todo tipo de barganha com o vício e com as inclinações naturais. Inclinações e paixões não podem ser tomadas como critérios para determinar o comportamento de seres racionais. Tais critérios seriam indignos do homem, rebarbativos (FARIA, 2007, p. 125, 126).

Kant, diferentemente de Aristóteles, não fundamenta sua ética sobre a ideia de um bem, que é interpretado como um fim visado em todos os atos humanos. Sua

heteronomia, mantendo-o em situação de "menoridade", e do qual, portanto, deve manter-se afastado (FARIA, 2007, p. 130).

15 Ao falarmos sobre os modelos tradicionais da ética, estamos citando as propostas éticas anteriores a Kant, em especial a ética aristotélica contida na Ética a Nicômaco a qual tem por fundamento da moral a "ideia de um bem que se apresenta como um fim visado em todos os atos humanos" (FARIA, 2007 , p. 125). Como também ao modelo ético cristão, cujo fundamento da moral seria o bem supremo que é interpretado como Deus.

16 FARIA, 2007, p. 125 apud ROSEN, Allen D., Kan's Theory of justice, USA: Cornell University Press 1993.

NASCIMENTO, Francisco Eliandro Souza do; SANTOS, Francisco Rogelio dos. A estrutura da moral kantiana. Griot : Revista 
ética fundamenta-se sobre o conceito de liberdade, que, na história da filosofia, não encontra similar nos conceitos de liberdade anteriores. Porém, o primeiro momento da liberdade em Kant, que é interpretado como espontaneidade (liberdade transcendental), "aparenta-se a ideia de Platão do libertar-se da prisão dos sentidos para contemplar, fora da caverna, o sol do bem" (SALGADO, 1995, p. 226).

A ideia de liberdade kantiana se contrasta com as concepções de liberdade existente nos filósofos anteriores a Kant, ficando ressalvada a influência de Rousseau no desenvolvimento do conceito kantiano de liberdade como autonomia (liberdade prática). Salgado, em sua obra $A$ idéia de justiça em Kant, cita alguns conceitos de liberdade anteriores a Kant e apresenta as contradições existentes entre o conceito de liberdade em Kant para com os demais. A primeira proposta de liberdade anterior a Kant que Salgado apresenta no capítulo V de sua obra é a definição aristotélica de liberdade. Cita o filósofo:

\begin{abstract}
A definição de Aristóteles contida na Metafísica - "livre é o homem que tem a si mesmo como fim e não o outro" desenvolvida com maior clareza, na Ética a Nicômaco, como um ato de escolha consciente do homem livre, já que “o que não é senhor de si mesmo é capaz de desejar, mas não de agir por livre escolha" (proaíresis) - não é o que se entende como autonomia no sentido kantiano, nem coincide com seu conceito de pessoa (fim em si mesmo), porque em Kant se trata de uma ideia, um dever ser com que pensamos todo ser humano, ao passo que em Aristóteles encontramos apenas a descrição do homem livre empiricamente, existente na Grécia: $O$ que age em função de si mesmo e não do outro é o oposto do escravo. (SALGADO, apud ARISTÓTELES, 1995, p. 226).
\end{abstract}

A filosofia prática de Kant se configura a partir do conceito de autonomia, que por sua vez tem como fundamento a ideia de liberdade e vontade. Kant insere uma nova proposta moral, no campo da filosofia prática. Ele estrutura sua filosofia moral sobre três pressupostos fundamentais que constituem a arquitetônica de sua ética, tais pressupostos são: o conceito de liberdade, conceito de boa vontade e o princípio de universalização da lei moral "imperativo categórico". No tópico a seguir analisaremos o que constitui cada item destes pressupostos morais.

\title{
Pressupostos fundamentais da moral kantiana
}

Todos os pressupostos contidos na arquitetônica da moral kantiana, conceito de vontade, conceito de boa vontade e o princípio de universalização da lei moral imperativo categórico -, fundamentam-se a partir da ideia de espontaneidade da ação, exposta na filosofia prática de Kant como uma propriedade da razão que possibilita a vontade, dos seres racionais, ser uma vontade livre. "Logo, a realidade da liberdade da vontade é feita condição da possibilidade da razão prática e de sua demonstração" (ROHDEN, 1981, p. 39). Em outros termos, a ética kantiana desenvolve-se e fundamenta-se a partir do conceito de vontade livre. Vejamos a seguir o que significa do conceito de vontade na filosofia prática kantiana e logo em seguida analisaremos o que constitui os seus pressupostos.

NASCIMENTO, Francisco Eliandro Souza do; SANTOS, Francisco Rogelio dos. A estrutura da moral kantiana. Griot : Revista 


\title{
A vontade
}

Kant define a vontade na derradeira seção da Fundamentação da Metafísica dos Costumes ${ }^{17}$, como:

\begin{abstract}
A vontade é uma espécie de causalidade dos sees vivos, enquanto racionais, e a liberdade seria a propriedade desta causalidade, pela qual ela pode ser eficiente, independentemente de causas estranhas que a determinem; assim como a necessidade natural é a propriedade da causalidade de todos os seres irracionais de serem determinados à actividade pela influência de causas estranhas (KANT, 2009, BA 97).
\end{abstract}

Na passagem citada, é apresentado o conceito de vontade livre como uma característica somente dos seres racionais. Pois, se a vontade é uma espécie de causalidade, e o atributo de tal causalidade é a liberdade, disso conclui-se que o filósofo de Königsberg apresenta-nos uma vontade livre, e que por meio dela "um ente dotado de razão como o homem distingue-se de simples entes naturais como os animais, que agem somente segundo leis dadas naturalmente, e não também segundo leis representadas". (Höffe, 2005, p. 188).

Na FMC podemos encontrar no mínimo três definições do conceito de vontade. Uma dessas definições, a de vontade como causalidade, já expomos no parágrafo anterior. Analisaremos as demais definições do conceito de vontade, contidos na FMC e na Crítica da Razão Prática ${ }^{18}$, para uma melhor compreensão da doutrina da boa vontade que será desenvolvida nesta unidade. Kant elabora na FMC outra definição de vontade, ele apresenta a vontade como o poder de um ente racional de agir segundo a representação de leis, ou seja, segundo princípios. Tal definição é extraída da seguinte passagem:

Tudo na natureza age segundo leis. Só um ser racional tem a capacidade de
agir segundo a representação das leis, isto é, segundo princípios, ou: só ele
tem uma vontade. Como para derivar as acções das leis é necessário a razão,
a vontade não é outra coisa se não razão prática. Se a razão determina
infalivelmente a vontade, as acções de um tal ser, que são conhecidas como
objectivamente necessárias, são também subjectivamente necessárias, isto
é, a vontade é a faculdade de escolher só aquilo que a razão,
independentemente da inclinação, reconhece como praticamente
necessário, quer dizer como bom (KANT, 2009, BA 37).

A definição de vontade ou a expressão "vontade" é compreendida por muitos, mais amplamente, como todo impulso de origem interna diferente de uma coerção externa. Se aceitarmos tal definição da expressão "vontade", teríamos que aceitar que simples entes naturais têm uma vontade, ao passo que obedecem a seus próprios impulsos e necessidades naturais. Porém, Kant define a vontade de maneira mais estrita, fazendo uma distinção entre impulsos de ação própria (vontade da natureza) que é uma característica dos entes naturais, e ação de acordo com leis representadas

\footnotetext{
17 A partir de agora será utilizado a sigla FMC para referenciar a obra Fundamentação da Metafísica dos Costumes.

${ }^{18}$ A partir de agora lê-se Crítica da Razão Prática como CRPr.
} 
(vontade própria ou vontade livre). Höffe, acerca da definição kantiana de vontade livre e de sua distinção de vontade da natureza, afirma que:

[...] em entes naturais os impulsos e as necessidades têm o significado de legalidade, de acordo com as quais se age com necessidade. Visto que o seu impulso interno é uma coerção interna, os meros entes naturais têm no máximo uma vontade no sentido metafórico. Eles, na verdade, seguem impulsos de ação próprios, mas não uma vontade própria e sim a "vontade da natureza". Só a capacidade de agir de acordo com leis representadas por si mesmo funda uma vontade própria (Höffe, 2005, p. 189).

Höffe expõe em seu texto que, da mesma maneira que Kant no âmbito teórico encontra uma distinção entre razão pura e razão empiricamente condicionada, a mesma coisa ocorre no âmbito prático. Tal distinção no âmbito prático é metodicamente clara, ela reside na compreensão de uma vontade dependente de fundamentos determinantes sensíveis e de uma vontade independente destes fundamentos, ou seja, a distinção reside entre a razão empiricamente dependente e a razão prática pura. $O$ elemento fundamental que justifica a distinção entre os dois conceitos de razão citados, descansa sobre o fato de que a razão prática empiricamente condicionada recebe a maioria da parte de sua determinação de fora, essas determinações manifestam-se em forma de impulsos e necessidades, paixões e hábitos, enquanto que a razão prática pura é independente de todas as condições empíricas.

Na Terceira sessão da FMC, Kant nos fornece, mais uma vez, outra definição do conceito de vontade, ele a define como um poder positivo, ou seja, uma causalidade da razão que dela derivam leis imutáveis que se expressam na forma de máximas, cujo princípio fundamental é o de "não agir segundo nenhuma outra máxima que não seja aquela que possa ter-se a si mesma por objeto como lei universal" (KANT, 2009, BA 99). Segundo Kant, "todos os homens se concebem como livres quanto à vontade" (KANT, 2009, BA 113).

A concepção kantiana de que todos os homens se compreendem como livres, funda-se a partir da definição da liberdade da vontade como independência da razão quanto a causas determinantes puramente subjetivas. Em Kant, esta independência da razão é uma propriedade de todos os seres racionais, todavia, o conceito que fundamenta esta independência da razão, conceito de liberdade da vontade, é um conceito puramente negativo, a liberdade ${ }^{19}$ e juntamente a definição de vontade compreende-se como uma espontaneidade que possibilita o libertar-se do homem perante o determinismo da natureza. Porém, como já havíamos citado, Kant na terceira seção da FMC define a vontade como um poder positivo. Cita o filósofo:

\footnotetext{
Aquele primeiro é apenas um pensamento negativo com respeito ao mundo sensível, o qual não dá leis à razão na determinação da vontade; só é positivo neste único ponto: que essa liberdade, como determinação negativa, está ligada ao mesmo tempo a uma faculdade (positiva) e até a
}

\footnotetext{
${ }^{19} \mathrm{O}$ conceito de liberdade expresso neste trecho faz menção ao primeiro momento da liberdade que é puramente negativo e interpretado como "uma causalidade pela qual algo acontece sem que a sua causa também seja determinada por uma outra causa anterior segundo leis necessárias, i. e., uma espontaneidade absoluta das causas (KANT, 2012, B 474).
}

NASCIMENTO, Francisco Eliandro Souza do; SANTOS, Francisco Rogelio dos. A estrutura da moral kantiana. Griot : Revista de Filosofia, Amargosa/Bahia, v.17, n.1, p.61-84, junho/2018. 
uma causalidade da razão a que chamamos uma vontade e que é a faculdade de agir de tal modo que o princípio das acções seja conforme ao carácter essencial de uma causa racional, quer dizer, à condição da validade universal da máxima como lei (KANT, 2009, BA 119).

$\mathrm{Na}$ CRPr, Kant repete inicialmente o mesmo ponto de vista da FMC, em que a vontade é definida como um poder de determinar a causalidade da razão mediante a representação de regras. Em seguida, Kant representa a vontade como um modo de relação entre a faculdade de desejar e o entendimento puro:

\begin{abstract}
Mas, além da relação em que se encontra com objetos (no conhecimento teórico), o entendimento possui também uma relação com a faculdade de apetição, que por isso se chama vontade, e chama-se vontade pura na medida em que o entendimento puro (que em tal caso chama-se razão) é pratico mediante a simples representação de uma lei. A realidade objetiva de uma vontade pura ou, o que é a mesma coisa, de uma razão prática pura, é dada a priori na lei moral como que mediante um factum; pois é assim que se pode denominar uma determinação da vontade que é inevitável, embora não dependa de princípios empíricos. No conceito de vontade, porém, já está contido o conceito de causalidade, por conseguinte no de uma vontade pura o conceito de uma causalidade com liberdade, isto é, não determinável segundo leis da natureza, conseqüentemente incapaz de uma intuição empírica como prova de sua realidade, todavia justifica perfeitamente, na lei prática pura a priori, a sua realidade objetiva, porém (como se pode facilmente vê-lo) não para o fim do uso teórico e sim do uso prático da razão (KANT, 2011, A 96 - 97).
\end{abstract}

Nesta passagem, o filósofo de Königsberg denomina a vontade como a relação entre a faculdade de desejar e o entendimento. O conceito de vontade é definido como vontade pura a partir do momento em que o entendimento puro passa a ser prático mediante representação de uma lei. Em todas as definições do conceito de vontade, contidos nesta unidade, "ação segundo a representação de leis", "ação segundo princípios" e "uma espécie de causalidade dos seres vivos", todas elas indicam atividades específicas da razão pura em determinar a vontade.

Feita a análise dos conceitos de vontade e chegando-se à compreensão de que "A vontade designa a capacidade de, em verdade, não extinguir os impulsos naturais e sim distanciar-se deles e de suspendê-los como fundamento determinante último" (Höffe, 2005, p. 189), poderemos assim então prosseguir na análise dos pressupostos fundamentais da moral kantiana, onde investigaremos o conceito de boa vontade como "o ponto de partida de toda a reflexão ética, pois sem uma boa vontade que é tal em si, 'sem nenhuma limitação', nada mais pode ser considerado moralmente bom" (CARMO, 2005, p. 19).

\title{
A boa vontade
}

A doutrina da boa vontade é exposta por Kant no início do texto da primeira seção ${ }^{20}$ da FMC como a única coisa que pode ser considerada como boa em si mesma.

\footnotetext{
20 "Esta secção consiste numa <<transição do conhecimento moral da razão vulgar para o conhecimento filosófico $>>$. O conhecimento em causa da $<<$ razão vulgar $>>$ não é mais do que o
} 
Kant a considera uma verdade fundamental para o pleno desenvolvimento dos talentos e qualidades do espírito. A boa vontade, diz ele, é a única coisa boa sem restrição, necessária para tornar bons todos os dons, tanto materiais, quanto espirituais e que estaria inteiramente contida na consciência comum. Diz o filósofo:

Discernimento, argúcia de espírito, capacidade de julgar e como quer que possam chamar-se os demais talentos do espírito, ou ainda coragem, decisão, constância de propósito, como qualidades do temperamento, são sem dúvida a muitos respeitos coisas boas e desejáveis; mas também podem tornar-se extremamente más e prejudiciais se a vontade, que haja de fazer uso destes dons naturais e cuja constituição particular por isso se chama carácter, não for boa. O mesmo acontece com os dons da fortuna. Poder, riqueza, honra, mesmo a saúde, e todo bem-estar e contentamento com sua sorte, sob o nome de felicidade, dão ânimo que muitas vezes por isso mesmo desanda em soberba, se não existir também a boa vontade que corrija a sua influência sobre a alma e juntamente todo o princípio de agir e lhe dê utilidade geral; isto sem mencionar o facto de que um espectador razoável e imparcial em face da prosperidade ininterrupta duma pessoa a quem não adorna nenhum traço duma pura e boa vontade, nunca poderá sentir satisfação, e assim a boa vontade parece constituir a condição indispensável do próprio facto de sermos dignos da felicidade. (KANT, 2009, BA 1 - 2). ${ }^{21}$

Para Kant, todos os talentos do espírito ou todas as qualidades do temperamento são vantajosos à boa vontade, porém tais talentos não contêm um valor total em si mesmo. Para que as qualidades do espírito possam ser consideradas boas e louváveis sem reservas, pressupõem os princípios da doutrina da boa vontade. Kant não estabelece, pois, teoricamente, este conceito, mas apenas evoca a pureza de intenção, que constitui a própria essência da boa vontade, que a consciência comum segue como regra, para julgar moralmente, tanto os talentos do espírito, quanto os

senso comum esclarecido em matérias morais. Partindo do que toma por senso comum, Kant começa por expor uma perspectiva sobre o valor da boa vontade. Para desenvolver essa perspectiva, centra depois a sua atenção no conceito de dever, elucidando-o sobretudo através de três proposições. Efectua depois a transição para o $<<$ conhecimento filosófico $>>$, tentando mostrar que o imperativo categórico (que só na seção seguinte será assim designado) é o princípio ético fundamental pressuposto nas concepções comuns de boa vontade e de dever. Kant conclui a secção com uma breve reflexão sobre a importância prática da filosofia (GALVÃO, Introdução da FMC, 2009, p. 15).

${ }^{21}$ Conforme ressalta Ferry, em algumas linhas do texto citado acima é possível observar a ruptura que Kant introduziu com o mundo antigo, em que sua filosofia moral se contrapõe as concepções antigas, naturalistas e aristocráticas da moral por afirmar que apenas a boa vontade pode ser considerada boa. Ferry esclarece porque apenas a boa vontade pode ser considerada boa. Segundo o autor, "a resposta é muito simples, e a argumentação, definitiva, mesmo que ambas repousem numa verdadeira revolução na definição do homem: é que, evidentemente, do novo ponto de vista que a antropologia de Rousseau permite pensar, nem os talentos naturais (aliás, considerados com razão pelo mundo antigo como repartidos de maneira bastante desigual) nem os interesses ou as "vantagens" adquiridas (a felicidade dos utilitaristas) definem a virtude em seja o que for. De fato, esta última só poderia residir no uso que é feito dos dons ou das vantagens que nos diferenciam dos outros. A prova? A força, a inteligência, a beleza e a riqueza podem muito bem ser qualidades ou atributos invejáveis, mas, no plano moral, evidenciam-se como axiologicamente neutras, pois todo o mundo reconhece que podemos utilizá-las tanto na direção do bem quanto na do mal! Como na parábola dos talentos, herdada do Evangelho, o que conta, de um ponto de vista moral, não é o capital de que dispomos no início, mas o uso, bom ou ruim, que dele fazemos" (FERRY, 2012, p.100).

NASCIMENTO, Francisco Eliandro Souza do; SANTOS, Francisco Rogelio dos. A estrutura da moral kantiana. Griot : Revista de Filosofia, Amargosa/Bahia, v.17, n.1, p.61-84, junho/2018. 
dons da fortuna, e, até mesmo, as qualidades da alma. Há, assim, um valor incondicionado na boa vontade, que se define pela bondade de nossa disposição interna, independente da consideração de qualquer fim que o homem se proponha. A vontade, na filosofia moral de Kant, será boa em si mesma, "na medida em que não for influenciada por elemento algum exterior a ela mesma. É nisso que consiste o seu pleno valor. Por ser boa em si mesma, constitui o bem supremo e a condição de tudo o mais" (RAUBER, 1999, p. 16).

Em Carmo, sobre a boa vontade, vamos encontrar o seguinte esclarecimento:

Os talentos e qualidades humanas, tais como coragem, capacidade de decisão, honra, etc, não têm valor por si mesmos; só podemos considerá-los valiosos se estiverem a serviço de uma boa vontade. Se não for assim, essas qualidades, boas em geral, podem tornar-se más e prejudiciais; como mostra o exemplo kantiano do sangue-frio de um facínora. Essa absolutidade do conceito de boa vontade faz com que ele inicie o livro anunciando com certa pompa que: "Neste mundo, e até também fora dele, nada é possível pensar que possa ser considerado como bom sem limitação a não ser uma só coisa: uma boa vontade" (CARMO, apud KANT, 2005, p. 19).

Na primeira seção da FMC, Kant parte do conhecimento racional comum acerca do conceito de moralidade, estabelecendo a boa vontade como a única coisa boa sem limitação. Segundo o filósofo, todo homem julga moralmente, e o objeto deste julgamento é a boa vontade, cuja ideia estaria presente no julgamento comum dos homens. Deste modo Kant funda o conceito de boa vontade, como o princípio fundante da moralidade, partindo de uma análise do conhecimento moral comum. Segundo Almeida:

[...] se a exigência kantiana de partir do "conhecimento racional comum" tem algum sentido preciso, este só pode consistir na indicação de que se trata de algo comum às diversas concepções e códigos morais. Ora, deve haver ao menos uma coisa que elas têm em comum e que é precisamente o que permite chamar a todas elas de concepções morais. Assim, determinar qual é este significado básico do predicado "moral" deve constituir o primeiro passo da reflexão filosófica kantiana sobre o conceito dado de moralidade. (ALMEIDA, Introdução da FMC, 2009, p. 17,18).

A reflexão filosófica kantiana sobre o conceito de moralidade partindo do conhecimento moral comum e em seguida a busca e estabelecimento do princípio supremo de moralidade, decorre da aparente compreensão de que não podemos falar de um conceito dado de moralidade no singular. As objeções levantadas a favor de tal impossibilidade fundamentam-se a partir da concepção de que as ideias sobre o que é lícito, proibido ou obrigatório, modificam-se de acordo com os grupos sociais e mesmo em cada grupo podem se modificar tais conceitos ao longo dos tempos. Na reflexão filosófica de Kant, sobre o conceito de moralidade, o filósofo estabelece o conceito de boa vontade juntamente com o de dever como algo comum entre as demais concepções morais. A necessidade kantiana de estabelecer um princípio supremo para a moralidade decorre da própria estrutura arquitetônica de sua ética, em que um dos pressupostos fundamentais é o critério de universalização das leis morais, porém, para que se possa estabelecer uma proposta moral de cunho universal 
é necessário que exista um princípio supremo de moralidade que seja comum às diversas concepções morais.

O termo boa vontade desenvolvido pelo filósofo de Königsberg na FCM designa a concepção da vontade moralmente boa e esta compreensão pressupõe a definição do que é moralmente bom como irrestritamente bom. A descrição kantiana do conceito de boa vontade, ou antes, do que é moralmente bom, parte da distinção que o filósofo faz entre o bom, o útil e o agradável. De acordo com Almeida:

[...] [a] distinção entre o bom, o útil e o agradável, mais precisamente, da suposição de que o conceito do bom tomado em sentido moral é especificamente distinto do conceito do bom no sentido do útil e do agradável. De fato, como o útil e o agradável têm de ser pensados, segundo a explicação kantiana, como aquilo que é bom sob uma condição subjetiva particular (que é, no caso do útil, a de ser um meio para um fim posto pelo indivíduo; no caso do agradável, ser prazeroso), o moralmente bom tem de ser definido como aquilo que é bom independentemente de qualquer condição subjetiva particular e, neste sentido, incondicionalmente bom. (ALMEIDA, Introdução da FMC, 2009, p. 27, 28).

Em Kant, a definição do que é moralmente bom, não parte de uma análise subjetiva particular, em que o conceito de bom está relacionado com o útil e o agradável. $\mathrm{O}$ bom, em sentido moral, não depende de nenhuma condição subjetiva particular a qual estabelece este conceito como algo prazeroso ou como um meio para atingir determinado fim, ele é considerado bom por ser incondicionalmente bom. A boa vontade possui um valor incondicionado, que se define pela bondade de nossa disposição interna, independente da consideração de qualquer fim que o homem se proponha, ela não é julgada pela utilidade ou inutilidade das ações e sim pela intenção, pois o que decide o valor moral de um ato é a pureza de intenção que impulsiona o agente à ação. Não é a felicidade ou qualquer fim que pode ser definido como moral, mas a realização da vontade boa sem interesses, apenas por si, a qual faz do homem um ser moral.

Para explicitar melhor o conceito de boa vontade, desenvolveremos no item a seguir o conceito de dever, que segundo Kant, contém em si o de boa vontade. Cita Kant:

Para desenvolver, porém, ó conceito de uma boa vontade altamente estimável em si mesma e sem qualquer intenção ulterior, conceito que reside já no bom senso natural e que mais precisa de ser esclarecido do que ensinado, este conceito que está sempre no cume da apreciação de todo o valor das nossas acções e que constitui a condição de todo o resto, vamos encarar o conceito do Dever que contém em si o de boa vontade, posto que sob certas limitações e obstáculos subjectivos, limitações e obstáculos esses que, muito longe de ocultarem e tornarem irreconhecível a boa vontade, a fazem antes ressaltar por contraste e brilhar com luz mais clara. (KANT, 2009, BA 8 - 9).

\section{0 dever}

Kant na FMC encara o conceito de dever tendo em vista o desenvolvimento do conceito de boa vontade que, de acordo com o filósofo ambos os conceitos estão 
relacionados, sendo inconveniente separá-los. Kant faz a distinção na FMC de ações que foram praticadas por dever (que tiveram por móbil a necessidade de uma ação por respeito à lei) das ações praticadas conforme ao dever onde seu fundamento foi uma inclinação imediata ou a intenção egoísta. O filósofo parte da distinção de ambas as ações, por dever ou conforme ao dever, tendo como meta expor em que consiste o dever e qual a sua relação com a boa vontade. Pois, para Kant, o valor do caráter de um homem, que é considerado moralmente sem qualquer comparação o mais alto, começa exatamente no que consiste em praticar uma boa ação, não por inclinação, mas por dever.

Almeida elaborou três proposições, partindo de uma análise da FMC, em que desenvolve o conceito de boa vontade ao lado do conceito de dever, vejamos:

\section{- Primeira proposição:}

Ter uma boa vontade consiste em estar decidido a agir por dever, não por inclinação. Kant baseia-a em duas considerações. A primeira é que não basta saber o que é bom para nos determinarmos a fazer o que é bom, visto que a nossa vontade pode ser afetada por inclinações sensíveis e podemos preferir seguir a inclinação a fazer o que sabemos ser bom. A segunda é que, para agir moralmente, não basta fazer o que é dever (ou seja, o que é moralmente bom para uma vontade que nem por isso faz necessariamente o que saber ser moralmente bom), mas é preciso fazer o que é dever porque é dever. Com efeito, se fazemos o que é dever, não por dever, mas porque é útil e agradável, nossa ação não satisfaz a definição inicial do que é bom em sentindo moral, que supomos especificamente distinto do que é bom no sentindo do útil e do agradável. É preciso, pois, distinguir a moralidade intrínseca do ato realizado por dever da legalidade ou conformidade extrínseca à lei moral, pois sem essa distinção não poderemos pensar o que é moralmente bom como irredutível ao meramente útil ou agradável. (ALMEIDA, Introdução da FMC, 2009, p. 29).

\section{- Segunda proposição:}

A segunda proposição é uma conseqüência imediata da anterior e diz que o que confere valor moral à ação é o princípio da ação, a saber, o princípio de agir por dever, não as conseqüências da ação, quais quer essas sejam (utilidade, agrado ou até mesmo a conformidade externa às leis morais). (ALMEIDA, Introdução da FMC, 2009, p. 29).

\section{- Terceira proposição:}

A terceira proposição se segue, por sua vez, das duas anteriores e diz que o dever é a ação necessária (segundo a lei moral) por respeito à lei moral. $\mathrm{O}$ termo "respeito" designa aí dois aspectos essenciais do modo como o homem e, de modo geral, todo ser racional dotado de uma sensibilidade, se relaciona à lei moral, isto é, o princípio dizendo o que é moralmente bom fazer. O primeiro é de natureza cognitiva e designa a "consciência da subordinação da nossa vontade à lei moral". O segundo é de natureza afetiva e designa o sentimento ambivalente que essa consciência necessariamente infunde em nós, pois este é ao mesmo tempo um sentimento de "alta estima" por aquilo que confere um valor irrestrito à vontade moralmente boa e um sentimento de temor ou aversão por aquilo 
que restringe nossas inclinações e escolhas. (ALMEIDA, Introdução da FMC, 2009, p. 30).

Kant, ao lado do conceito de boa vontade, desenvolve o conceito de dever, "poder-se-ia dizer até que a boa vontade é a vontade de agir por dever" (PASCAL, 1992, p.112). O dever é definido por Kant como a necessidade de cumprir uma ação por puro respeito à lei. $O$ filósofo faz a distinção entre a ação feita conforme ao dever a qual foi realizada por intenção egoísta ou por inclinação imediata, de uma ação praticada por dever que teve como fundamento o puro respeito à lei moral. Para explicitar esta distinção, Kant recorre a três exemplos ilustrativos. Observemos:

A) O primeiro exemplo trata de um comerciante que atende sua clientela honestamente ${ }^{22}$ :

É na verdade conforme ao dever que o merceeiro não suba os preços ao comprador inexperiente, e, quando o movimento do negócio é grande, o comerciante esperto também não faz semelhante coisa, mas mantém um preço fixo geral para toda a gente, de forma que uma criança pode comprar em sua casa tão bem como qualquer outra pessoa. É-se, pois, servido honradamente; mas isso ainda não é bastante para acreditar que o comerciante tenha assim procedido por dever e princípios de honradez; o seu interesse assim o exigia; mas não é de aceitar que ele além disso tenha tido uma inclinação imediata para os seus fregueses, de maneira a não fazer, por amor deles, preço mais vantajoso a um do que a outro. A acção não foi, portanto, praticada nem por dever nem por inclinação imediata, mas somente com intenção egoísta (KANT, 2009, BA 9 - 10).

B) No segundo exemplo, Kant aborda o dever em conservar cada qual a sua vida, esclarecendo que a verdadeira ação moral não deve receber influência das inclinações particulares: ${ }^{23}$

Pelo contrário, conservar cada qual a sua vida é um dever, e é além disso uma coisa para que toda a gente tem inclinação imediata. Mas por isso mesmo é que o cuidado, por vezes ansioso, que a maioria dos homens lhe dedicam não tem nenhum valor intrínseco e a máxima que o exprime nenhum conteúdo moral. Os homens conservam a sua vida conforme // ao dever, sem dúvida, mas não por dever. Em contraposição, quando as contrariedades e o desgosto sem esperança roubaram totalmente o gosto de viver; quando o infeliz, com fortaleza de alma, mais enfadado do que desalentado ou abatido, deseja a morte, e conserva contudo a vida sem a amar, não por inclinação ou medo, mas por dever, então a sua máxima tem um conteúdo moral (KANT, 2009, BA 10).

22 Conforme ressalta J. Carmo, o comerciante "age de acordo com o dever, ou seja, conforme ao dever, mas não por dever. Ele age honestamente somente porque isso lhe parece mais vantajoso. Para Kant não é ação como tal que é boa, mas somente aquela que se pauta numa vontade correspondente. A ação com valor moral é aquela que é conforme ao dever e, além disso, é realizada com consciência do dever" (CARMO, 2005, p. 19).

${ }^{23}$ Segundo J. Carmo, neste exemplo, "Kant esclarece que a verdadeira ação moral também não deve receber influência das inclinações e disposições naturais. Neste segundo exemplo, Kant mostra que não há valor moral em preservar a vida se nos encontramos com alegria de viver e todas as nossas disposições naturais se inclinam para isso. Valor moral existe no ato de preservar a vida mesmo quando o agente não encontra mais alegria de viver - seja por que motivo for -, e, mesmo assim preservar a vida tão somente porque este é seu dever" (Idem).

NASCIMENTO, Francisco Eliandro Souza do; SANTOS, Francisco Rogelio dos. A estrutura da moral kantiana. Griot : Revista 
C) O terceiro é o de um filantropo insensível que realiza uma ação benevolente: ${ }^{24}$

Admitindo pois que o ânimo desse filantropo estivesse velado pelo desgosto pessoal que apaga toda // a compaixão pela sorte alheia, e que ele continuasse a ter a possibilidade de fazer bem aos desgraçados, mas que a desgraça alheia o não tocava porque estava bastante ocupado com a sua própria; se agora, que nenhuma inclinação o estimula já, ele se arrancasse a esta mortal insensibilidade e praticasse a acção sem qualquer inclinação, simplesmente por dever, só então é que ela teria o seu autêntico valor moral. Mais ainda: - Se a natureza tivesse posto no coração deste ou daquele homem pouca simpatia, se ele (homem honrado de resto) fosse por temperamento frio e indiferente às dores dos outros por ser ele mesmo dotado especialmente de paciência e capacidade de resistência às suas próprias dores e por isso pressupor e exigir as mesmas qualidades dos outros; se a natureza não tivesse feito de um tal homem (que em boa verdade não seria o seu pior produto) propriamente um filantropo, - não poderia ele encontrar ainda dentro de si um manancial que lhe pudesse dar um valor muito mais elevado do que o dum temperamento bondoso? Sem dúvida! - e exactamente aí é que começa o valor do carácter, que é moralmente sem qualquer comparação o mais alto, e que consiste em fazer o bem, não por inclinação, mas por dever. (KANT, 2009, BA 11).

A ação que em sua máxima contém um conteúdo moral é aquela que é praticada por dever, ou seja, por puro respeito à lei. $O$ valor moral de uma ação praticada por dever não reside no propósito que com ela se quer atingir, e sim no princípio subjetivo que determina a ação. Nos exemplos citados por Kant, podemos observar três ações em que cada uma delas teve como fundamento uma máxima diferente, porém somente a ação que teve como móbil a necessidade incondicionada de uma ação por puro respeito à lei moral, pode ser considerada uma ação por dever e sua máxima possui um conteúdo moral. No primeiro exemplo, a ação não foi praticada por dever e sim conforme ao dever, pois o móbil de sua ação foi à intenção egoísta em não subir os preços ao comprador inexperiente acreditando ser mais vantajoso aos seus negócios. $O$ segundo exemplo também fornece uma ação conforme ao dever, porém sua máxima não contém um conteúdo moral, pois o que motivou a ação foi a inclinação imediata em conservar a vida quando nos encontramos com alegria de viver e não o respeito à lei em que é um dever preservar a vida independente de qualquer situação. $O$ último exemplo diferencia-se dos demais, pois o princípio subjetivo que determinou a ação do filantropo, em praticar a ação sem qualquer inclinação, simplesmente por dever, possui um conteúdo moral, haja vista que o móbil de tal ação foi a necessidade de uma ação por respeito à lei. Assim para Kant:

\footnotetext{
24 J. Carmo ressalta que, "na perspectiva kantiana, a ação deste filantropo insensível, realizada apenas por dever, merece mais apreço do que a realizada por outro que o faz porque sente prazer em promover o bem. Aqui Kant distancia-se de uma posição de larga aceitação no senso comum. Segundo esta concepção, amplamente difundida, só quando ajudamos alguém por inclinação, simpatia ou bondade, nossa ação tem verdadeiro valor moral. Kant defende a posição contrária de que a ação só é verdadeiramente moral quando ocorre por dever e não por inclinação, nem por um propósito externo qualquer" (CARMO, 2005, p. 19, 20).
} 
O valor moral da acção não reside, portanto, no efeito que dela se espera; também não reside em qualquer princípio da acção que precise de pedir o seu móbil a este efeito esperado. Pois todos estes efeitos (a amenidade da nossa situação, e mesmo o fomento da felicidade alheia) podiam também ser alcançados por outras causas, e não se precisava portanto para tal da vontade de um ser racional, na qual vontade — e só nela — se pode encontrar o bem supremo e incondicionado. Por conseguinte, nada senão a representação da lei em si mesma, que // em verdade só no ser racional se realiza, enquanto é ela, e não o esperado efeito, que determina a vontade, pode constituir o bem excelente a que chamamos moral, o qual se encontra já presente na própria pessoa que age segundo esta lei, mas se não deve esperar somente do efeito da acção (KANT, 2009, BA 15 - 16).

Kant estabelece como uma ação moral aquela em que a vontade não teve como fundamento nenhum outro móbil senão a representação da lei em si mesma, pois somente a representação de tal lei deve determinar nossa vontade, para que nossa ação possa constituir o bem excelente a que chamamos moral. Porém que lei "pode ser então essa, cuja representação, mesmo sem tomar em consideração o efeito que dela se espera, tem de determinar a vontade para que esta se possa chamar boa absolutamente e sem restrição (KANT, 2009, BA 17)?" Esta lei, segundo Kant, é a lei universal das ações em geral, o qual deve servir de único princípio à vontade. Para que uma ação seja considerada moral a máxima (princípio subjetivo do querer) que determina o agente deve entrar em conformidade com a lei universal, que de acordo com Kant, se manifesta da seguinte maneira, "devo proceder sempre de maneira que eu possa querer também que a minha máxima se torne uma lei universal" (KANT, 2009, BA 17).

Kant, perante a deficiência da vontade racional, em que a mesma não é absolutamente boa, por estar sujeita a ser determinada pela inclinação imediata ou pela intenção egoísta, tem o intuito de apresentar e fundamentar um preceito que possa sanar essa deficiência da vontade racional. ${ }^{25}$ Rauber ressalta que o objetivo de Kant em expor e fundamentar tal formula, resulta da:

Necessidade de se estabelecer uma lei prática ordenada pela própria razão, capaz de determinar o que é bom conforme à razão e não conforme às paixões humanas, movidas pelas inclinações sensíveis. Dar-se-á ênfase, pois, ao imperativo que expressa a necessidade objetiva de uma ação por si, independente de qualquer intenção ou finalidade. Esse imperativo também é denominado por Kant de imperativo da moralidade (Imperativ der Sittlichkeit). (RAUBER,1999, p.23).

\footnotetext{
25 Pascal afirma que esta deficiência da vontade racional reside em um conflito entre a razão e a sensibilidade. Segundo o filosofo, "Há, assim, um conflito entre a razão e a sensibilidade na determinação da vontade. A vontade não obedece a razão salvo se for constrangida por ela, e não naturalmente, como o faria se fosse pura. É por esse motivo que as leis da razão se apresentam a vontade como mandamentos, como imperativos. Uma vontade perfeitamente boa, uma vontade santa - a vontade divina, por exemplo - obedeceria às leis racionais sem ser coagida por elas; estas leis não seriam pois imperativos. Para uma vontade humana, ao contrário, elas se apresentam sob a forma de imperativo, ou seja, como deveres" (PASCAL, 1992, p. 120).
}

NASCIMENTO, Francisco Eliandro Souza do; SANTOS, Francisco Rogelio dos. A estrutura da moral kantiana. Griot : Revista 
No item a seguir será desenvolvido o imperativo da moralidade, o qual Kant apresenta na FMC como o critério da moral e o fundamenta como o princípio supremo da moralidade, que é suficiente para determinação do dever em caso de conflito moral. Kant denomina este imperativo de imperativo categórico.

\section{Imperativo categórico}

Existem dois tipos de imperativos estabelecidos por Kant como comandos emitidos pelo espírito humano que devem determinar as ações de cada individuo: os imperativos hipotéticos e os imperativos categóricos. Há, no primeiro imperativo, resíduo de conteúdo subjetivo, que serve como mola propulsora dos atos. Podemos citar novamente dois exemplos clássicos postos por Kant na FMC, acerca de determinadas ações que tiveram como mola propulsora o imperativo hipotético. "O primeiro é o do suicídio: por amor a mim mesmo, tomo como máxima encurtar minha vida caso ela, prolongando-se, me ameaça mais com desgraças do que com alegria" (RAUBER, 1999, p.27). Pode-se observar neste exemplo que o motivo da ação foi um sentimento particular, visando somente o benefício próprio e não o respeito a uma lei universal de preservar a vida em quaisquer circunstâncias. $O$ segundo exemplo, como já exposto acima, trata de um merceeiro que agindo também por meio de imperativos que ordenam hipoteticamente, e pode ser formulado da seguinte maneira: se queres $A$, então deves $B$, não sobe seus preços ao comprador inexperiente, quando o movimento do negócio é grande, visando a um fim mais proveitoso o qual lhe trará inúmeros benefícios.

O que levou o agente dos exemplos citados acima, a proceder de tal modo, foi um fim específico "particular", visando um meio para atingir um determinado êxito e não a observação da lei moral que se impõe como regra universal. Se uma ação for realizada como meio para lograr um êxito, o imperativo que atribuímos a tal ação deve ser hipotético não categórico, haja vista que o motivo que levou o agente a realizar tal ação foi um fim subjetivo e não a necessidade incondicionada, de validade universal da lei prática. Uma obrigação (ou imperativo) é hipotética quando existe apenas em certas condições, mas não noutras, se o agente abandonar o desejo relevante, a obrigação desaparece também. Já no imperativo categórico, não há "resíduo algum de conteúdo subjetivo, há sim uma forma racional objetiva sem finalidade" (APOLINÁRIO, 2012, p. 45). O imperativo categórico é desenvolvido por Kant como principio supremo da moralidade, ele é o critério do agir moral.

Os imperativos apresentados por Kant na FMC exprimem-se pelo verbo dever, que orientam o agir humano, ou seja, dizem o que se deve fazer em determinada situação, apresentando "qual das possibilidades de ação é boa por estar em conformidade com os príncipios objetivos, válidos para todos os seres racionais" (RAUBER, 1999, p. 22). Estes imperativos podem ordenar de forma hipotética, de acordo com os exemplos citados acima que exprimem o modelo de ação como condição para a obtenção de determinado fim, ou catégorica que exprime o modelo de ação por puro respeito à necessidade incondicionada, de validade universal da lei moral. Em síntese, cita Pascal que os imperativos dinstuinguem-se entre duas classes. Vejamos:

NASCIMENTO, Francisco Eliandro Souza do; SANTOS, Francisco Rogelio dos. A estrutura da moral kantiana. Griot : Revista 
Ora, podem distinguir-se duas classes de imperativos: os imperativos hipotéticos e os imperativos categóricos. Aqueles nos apresentam uma ação como necessária para alcançar um certo fim. Estes nos propõem uma ação como necessária em si mesma, incondicionalmente. Por exemplo: os imperativos da habilidade, que nos prescrevem os meios úteis para obter um certo resultado, são hipotéticos. Hipotéticos são também os imperativos da prudência, que nos prescrevem os meios mais seguros para alcançar a felicidade. O imperativo da moralidade, ao contrário, nos prescreve uma certa conduta, independentemente de todo outro fim. Ele não nos diz: "Faze isto se queres ter bom êxito ou se queres ser feliz", mas tão somente: "Faze isto". A habilidade dita regras, a prudência dá conselhos, a moralidade impõe mandamentos ou leis. (PASCAL, 1992, p. $120)$.

O imperativo categórico expressa "a necessidade de uma ação como fim em si mesma, sem relação com qualquer outra finalidade" (RAUBER, 1999, p.22). Ele é desenvolvido por Kant na forma de uma lei universal, que implica não só universalidade como também imputabilidade e incondicionalidade. Ele pode ser representado através da seguinte fórmula, como já visto acima, "devo proceder sempre de maneira que eu possa querer também que a minha máxima se torne uma lei universal" (KANT, 2009, BA 17). O imperativo categórico representa apenas a pura forma da lei universal, sem nenhuma determinação material, isto é, de conteúdo. Haja visto que, enquanto formulação da lei moral, o imperativo categórico é estritamente formal, pois não indica exatamente o conteúdo do dever, apenas indica o caminho a ser seguido para o agir com mérito moral. Porém, depois Kant desenvolve a fórmula acima em mais três, dando uma definição de conteúdo a cada uma delas.

A fórmula da lei imperativa da moralidade exige que a minha ação seja universalizada por meio da conformidade da máxima com a lei universal. Elas servem como bússola para determinar como devo agir perante uma determinada situação.

A fórmula geral do Imperativo categórico, se desdobra em outras três fórmulas que determinam o seu conteúdo. Pois de acordo com Sousa, "uma forma absolutamente genérica seria vazia e por isso precisa de uma matéria (na $K p V$ [Crítica da Razão Prática], Kant só preserva a fórmula geral)" (SOUZA, 2004, p. 89). Vejamos as outras formulas que Kant desenvolveu a partir da fórmula geral do Imperativo categórico:

I" fórmula - "Age como se a máxima da tua ação se devesse tornar, pela tua vontade, em lei universal da natureza" (FMC, BA 52). Kant, acerca desta fórmula, afirma que ela pode, assim, ser formulada a partir da consideração de que, "a universalidade da lei, segundo a qual certos efeitos se produzem, constitui aquilo a que se chama propriamente natureza no sentido mais lato da palavra (quanto à forma), quer dizer realidade das coisas, enquanto é determinada por leis universais" (FMC, idem).

2 fórmula - "Age de tal maneira que uses a humanidade, tanto na tua pessoa, como na pessoa de qualquer outro, sempre e simultaneamente, como fim e nunca simplesmente como meio" (KANT, 2009, BA 67). Essa fórmula é denominada, pelos estudiosos de Kant, de fórmula do "fim em si". Pois o ser racional é o único ser que existe como "fim em si mesmo". O

NASCIMENTO, Francisco Eliandro Souza do; SANTOS, Francisco Rogelio dos. A estrutura da moral kantiana. Griot : Revista 
valor de todas as coisas, e de todos os seres irracionais, só tem validade por estarem relacionados ao homem, só ele manifesta valor absoluto. Portanto, o homem, como fim em si mesmo, jamais deve servir de meio. Segundo Sousa, "Fica implícita aqui a condenação, por parte de Kant, de qualquer tipo de sociedade que se fundamente na exploração do homem pelo homem" ${ }^{26}(\mathrm{SOUZA}, 2004$, p. 89).

3 " fórmula - "Age de tal maneira que a ideia da vontade de todo ser racional possa ser concebida como vontade legisladora universal" (KANT, 2009, BA 71).

Entre todas as formulações do imperativo categórico expostas até aqui, esta última é a que representa a determinação completa de todas máximas, seu objetivo é integrar a conduta de todos os seres racionais como legisladores universais.

Para Kant, o homem não pode ser tratado como instrumento, pois ele não deve ser objeto da legislação universal colocada pela lei moral, deverá ser ele mesmo autor da lei moral que determina sua vontade. Ele não deve receber sua lei de fora, deve se autodeterminar impondo a lei a si mesmo. Segundo Kant, este é o ápice da moral humana, que é o princípio da autonomia da vontade em dar leis a si mesmo.

\section{Considerações finais}

Nosso artigo buscou apresentar a fundamentação da filosofia prática em Kant, expondo os principais pressupostos da filosofia kantiana, tratamos dos conceitos de vontade, boa vontade, dever e imperativo categórico como a estrutura arquitetônica da moral kantiana. $O$ conceito de vontade, o qual o filósofo alemão apresenta como uma espécie de causalidade dos seres vivos, enquanto racionais, e a propriedade desta causalidade é o conceito de liberdade. Para Kant, a vontade designa a capacidade de suspender os impulsos naturais como fundamento determinante último, possibilitando através da formulação da lei moral o processo de autonomia. Passamos ainda do conceito de vontade para o de boa vontade, o qual é apresentado por Kant, como a única coisa boa, sem restrição, necessária para tornar bons todos os dons. A boa vontade é interpretada como a porta de entrada para que a moralidade chegue ao seu acabamento, que é o cumprimento do dever. Segundo o filósofo, ela possui um valor incondicionado, que se define pela bondade de nossa disposição interna, independente da consideração de qualquer fim que o homem se proponha. Ao lado deste conceito desenvolvemos o conceito de dever, que segundo Kant, contém em si o de boa vontade.

O dever é definido por Kant como a necessidade de cumprir uma ação por puro respeito à lei. $O$ filósofo faz a distinção entre a ação feita conforme ao dever a qual foi realizada por intenção egoísta ou por inclinação imediata, de uma ação praticada por dever que teve como fundamento o puro respeito à lei moral. Para

\footnotetext{
26 “Esta fórmula é considerada por Lucien Goldmann como a mais radical condenação da sociedade burguesa e a fundamentação de todo o humanismo futuro [depois de Kant]: "Se compreendemos que esta fórmula condena toda sociedade baseada na produção para o mercado, na qual os outros homens são tratados como meio, a fim de se realizar o lucro, daremos conta de até que ponto a moral kantiana é uma moral de conteúdo e até que ponto ela é uma recusa radical da sociedade existente" (SOUZA, 2004, p.90).
}

NASCIMENTO, Francisco Eliandro Souza do; SANTOS, Francisco Rogelio dos. A estrutura da moral kantiana. Griot : Revista de Filosofia, Amargosa/Bahia, v.17, n.1, p.61-84, junho/2018. 
Kant, a ação que em sua máxima contém um conteúdo moral é aquela que é praticada por dever, ou seja, por puro respeito à lei. $O$ valor moral de uma ação praticada por dever não reside no propósito que com ela se quer atingir, e sim no princípio subjetivo que determina a ação. Concluímos esta exposição da arquitetônica kantiana com a definição do imperativo da moralidade, imperativo categórico, por meio da seguinte fórmula "devo proceder sempre de maneira que eu possa querer também que a minha máxima se torne uma lei universal".

Os pressupostos apresentados até aqui constituem a base da filosofia moral de Kant. A proposta moral kantiana fundamenta-se e estrutura-se sobre o conceito de autonomia. O princípio da autonomia é interpretado por Kant como, "não escolher senão de modo a que as máximas da escolha estejam incluídas simultaneamente, no querer mesmo, como lei universal" (KANT, 2009, BA 87). Para Kant, o princípio da autonomia é o único princípio da moral, pois tal princípio se manifesta na forma de um imperativo categórico, pois este comando emitido pela razão não ordena nada mais nada menos que precisamente a autonomia da vontade em dar lei a si mesma. 


\section{Referências bibliográficas}

ABBAgnaNO, Nicolas. Dicionário de Filosofia. São Paulo: Martins Fontes, 1998. AgOSTINI, Leonardo. Autonomia: Fundamento da dignidade humana em Kant. Dissertação: Mestrado em Filosofia, Pontifícia Universidade Católica do Rio Grande do Sul. Porto Alegre: PUCRS, 2009.

ALLISON, Henry, E. El idealismo trascendental de Kant: una interpretación y defensa. Prólogo y traducción de Dulce María Granja Castro. - Barcelona: Anthropos; México: Universidad Autónoma Metropolitana - Iztapalapa, 1992.

APOLINÁRIO, José Antônio Feitosa. Nietzsche e Kant: sobre a crítica e a fundamentação da moral. Recife: Ed. Universitária da UFPE, 2012.

ARISTÓTELES. Ética a Nicômaco. Brasília: Editora UNB, 2002.

CARMO, J. A. D. A universalização como critério moral: Kant e Apel. Fortaleza: UFC, 2005.

CARMO, L. A. D. A reflexão filosófica transcendental. Fortaleza: EdUECE/ ABREU, 2013.

FARIA, Maria do Carmo Bettencourt de. Direito e ética: Aristóteles, Hobbes, Kant. São Paulo: Paulus, 2007.

FERRY, Luc. Kant: uma leitura das três "Críticas". 3. ed. - Rio de Janeiro: DIEFEL, 2012.

KANT, Immanuel. A Metafísica dos costumes. Bauru: EDIPRO, 2008.

Iluminuras, 2006.

Antropologia de um ponto de vista pragmático. São Paulo:

Crítica da razão pura. Rio de Janeiro: Vozes, 2012.

.Crítica da razão prática. 3. ed. - São Paulo: Editora WMF Martins

Fontes, 2011.

.Fundamentação da metafísica dos costumes. Lisboa: Edições 70, 2009.

Editorial, 2009.

.Fundamentação da metafísica dos costumes. São Paulo: Discurso

.Textos seletos. Petrópolis: Vozes, 2013.

MARCONDES, Danilo. Textos básicos de filosofia: dos pré-socráticos a Wittgenstein. 5. ed. revista. Rio de Janeiro: Jorge Zahar Ed.,2007.

OLIVEIRA, Manfredo Araújo de. Ética e sociabilidade. São Paulo: Loyola, 1996.

HECK, José N. “A dupla legislação e a classificação dos deveres em Kant”. In: Justiça e política: homenagem a Otfried Höffe. Oliveira e Souza (org.). Porto Alegre: EDIPUCRS, 2003.

HÖFFE, Otfried. Immanuel Kant. São Paulo: Martins Fontes, 2005.

PASCAL, Georges. O pensamento de Kant. Rio de Janeiro. Vozes, 1992.

RAUBER, Jaime José. O problema da universalização em ética. Porto Alegre: EDIPUCRS, 1999.

ROHDEN, Valério. Interesse da razão e liberdade. São Paulo: Ática, 1981.

SALGADO, Joaquim Carlos. A ideia de justiça em Kant: seu fundamento na liberdade e na igualdade. 2. ed. Belo Horizonte: Editora UFMG, 1995.

SOUZA, Oscar d'Alva e, filho. Ética individual e ética profissional: princípios da razão feliz. Fortaleza: ABC,1998.

NASCIMENTO, Francisco Eliandro Souza do; SANTOS, Francisco Rogelio dos. A estrutura da moral kantiana. Griot : Revista 
TAVARES, Manuel; FERRO, Mário. Análise da obra fundamentação da metafísica dos costumes de Kant. 2. ed. Lisboa: Editora Presença,1997.

VÁZQUEZ, Adolfo Sánchez. Filosofia e circunstância. Rio de Janeiro: Civilização Brasileira, 2002.

2007.

Ética. 29. ed. Rio de Janeiro: Civilização Brasileira,

VAZ, Pe. Henrique C. de Lima. Antropologia Filosófica I. 4. ed. São Paulo: Loyola, 1998.

São Paulo: Loyola, 2002. . Escritos de filosofia IV: introdução à ética filosófica 1.

WOOD, A. Kant's Compatibilism. In: WOOD, Allen W. Self and Nature in Kant's Philosophy. London: Cornell University Press, 1984.

Contribuição dos autores:

Francisco Eliandro Souza do Nascimento e Francisco Rogelio dos Santos participaram da discussão, redação e revisão do artigo. Os autores aprovaram a versão final do texto.

Autor(a) para correspondência: Francisco Eliandro Souza do Nascimento, Universidade Federal do Ceará, Av. Universidade, 2995, Benfica, CEP 60020-181, Fortaleza - CE, Brasil. francisco_eliandro@hotmail.com 